\title{
AIDS e Sua Origem
}

Parece não haver dúvidas quanto o caráter novo da pandemia mundial de AIDS. Os primeiros casos foram detectados na África e nos Estados Unidos e a epidemia passou a adquirir importância no decurso do decênio de 1980. Não obstante, constitui ainda mistério a questão de sua origem. Admitindo-se como correta a hipótese de que o vírus precursor tenha passado de primatas para o homem, permanece sem explicação plausivel o mecanismo pelo qual isso teria ocorrido. $\mathrm{E}$ mais ainda, porque após milhares de anos de coexistência de homens e primatas no Continente Africano, somente agora se deu a emergência da infecção humana pelo vírus aidético.

A guisa de pano de fundo, há que se considerar o conceito de nidalidade para os agentes infecciosos e as múltiplas maneiras pelas quais eles interagem com seus hospedeiros, dentre os quais o homem. Se dessas interações resultam comunidades, as populaçð̄es que delas participam têm seu próprio papel na repartição dos recursos disponiveis e ao qual se dá o nome de nicho ecológico de cada população, ou seja, de cada espécie (Forattini, 1992). Quando esta é representada por um agente infeccioso, a infecção que ele determina pode vir a desaparecer, local ou temporariamente, se ele se revelar ineficiente na transmissão. Em outras palavras, se, em média, a cada hospedeiro atual suceder menos de um novo. Obviamente, vários são os fatores para que essa situação ocorra, tanto naturais como artificiais. Dentre os primeiros pode-se mencionar o desenvolvimento da imunidade ou o desaparecimento da população hospedeira, enquanto os segundos referem-se às medidas de saúde pública. No que concerne à AIDS, há que se considerar mais de um agente viral HIV, muito semelhantes aos SIV, ou seja, os vírus da imunodeficiência simiana. Assim sendo, embora os primeiros óbitos atribuíveis a essa causa possam ter ocorrido nos anos 1950, acredita-se que a infecção tenha surgido nas regizes africanas central e oriental, uma vez que ali teve início sua maior frequência e onde a infecção de primatas ocorre na natureza.

Diante disso surgiu a tendência a se aceitar a hipótese de que o vírus da AIDS tenha se difundido na população humana a partir de sua presença em populaçőes de macacos. Ou seja, que tenha encontrado a possibilidade de ocupar nicho ecológico interativo com o homem. O mecanismo graças ao qual isso possa ter ocorrido, não está ainda esclarecido. Vários são os aspectos que demandam explicações. Em primeiro lugar, a aparente benignidade da infecção por SIV entre primatas, contrastando com a extrema virulência da AIDS humana. Em segundo lugar e como já se mencionou, o porquê de, após milhares de anos de convivência, só agora deu-se a manifestação epidemiologicamente detectável da doença. Essas questroes, ao que parece, constituem o âmago da misteriosa origem da AIDS.

Várias são as hipóteses que podem ser aventadas para desvendá-las. Desde a simples questão de oportunidade e desta vir a se tornar mais freqüente em virtude das mudanças sociais resultantes da aglomeração urbana e do intercâmbio extremamente desenvolvido. Há também os que admitem a influência das transfusð̌es sangüínas experimentais realizadas, no decurso deste século, para estudos de malária. Contudo, nenhuma delas é capaz de trazer explicaçőes incontestes sobre a questão (Diamond, 1992). Em vista disso, torna-se lícito que outras teorias possam vir a ser aventadas.

É sabido que os agentes infecciosos apresentam a possibilidade de emergirem sob novas formas para dar origem a epidemias. Algumas revelam-se associadas às mudanças do comportamento humano enquanto outras surgem de novas espressð̃es gênicas (Krause, 1992). Estas podem ser representadas por mutação que atinge somente um único nucleotídeo da cadeia do DNA e, mesmo assim, ser essencial para o desenvolvimento da virulência. É conhecido o fato de a rapidez da taxa mutacional do HIV resultar em grande potencial de mudanças nas taxas de replicação. É por isso que, fora do periodo de latência, o vírus desenvolve-se intensamente no intervalo entre o surgimento dos sinais clínicos e a morte (Ewald, 1993). Por sua vez, o progresso da invasão antropogênica de qualquer espécie, ao longo do processo de homogeneização dentre as populações da comunidade invadida, está na dependência de fatores essencialmente dinâmicos. Em outros termos, a natureza das interações dessa espécie com as outras da comunidade invadida é a determinante do sucesso dessa invasão (Lodge, 1993). Porém, para que esse processo tenha sucesso e logre a estabilidade, essa interação deverá dar origem a novo nicho ecológico, ou então, assentar-se sobre nicho deixado vago. Esta última possibilidade torna-se admissível ao se considerar a atuação do ser humano extinguindo espécies da biosfera. E essa extinção não deve ser encarada apenas como a de animais e plantas no decurso das macro-alteraçðes ambientais, mas sim também como resultado conscientemente colimado ao se planejar campanha de erradicação de doença infecciosa. Esta, sob o ponto de vista ecológico, nada mais representa do que a extinção de, pelo menos, uma espécie, a do agente infeccioso. Em logrando êxito, dá-se a vacância de um nicho, que poderá vir a 
ser ocupado por outro. Talvez seja simples coincidência e, portanto, não se trata de estabelecer afirmaçōes. Porém, não deixa de ser interessante ponderar que, no tempo, à erradicação mundial da variola sucedeu a pandemia de AIDS. E, no espaço, aquela tenha sido supostamente extinta por último, na Affrica, e esta tenha se originado, por primeiro, no mesmo Continente. Em outras palavras, poderia ter-se dado o caso de que os vírus SIV, pré-existentes e relativamente inócuos, estivessem "aguardando" essa oportunidade.

São Paulo, junho, 1993

\author{
Oswaldo Paulo Forattini \\ Editor
}

Departamento de Epidemiologia

Faculdade de Saúde Pública da

Universidade de São Paulo

\title{
Referéncias Bibllográficas
}

- Diamond, J. - The mysterious origin of AIDS, Natural History, 101(9): 25-9, 1992.

- Ewald, P.W. - The evolution of virulence. Sci. Amer., 268(4): 56-62, 1993.

- Forattini, O.P. - Ecologia, epidemiologia e sociedade. São Paulo, Editora da Universidade de São Paulo/Livraria Editora Artes Médicas Ltda., 1992.

- Krause, R.M. - The origin of plagues: old and new. Science, 257: 1073-1078, 1992.

- Lodge, D. M. - Biological invasions: lessons for ecology. Trends Ecol. Evol., 8: 133-7, 1993. 


\section{AIDS and Its Origin}

The worldwide AIDS epidemic is clearly new. The first cases occurred in Africa and the United States and the epidemic gained serious proportions during the eighties. However, the question of its origin still remains a mystery. Assuming as correct that the precursor AIDS virus spread from monkeys to humans, complete explanations as to how it could have happened are still not available. It is a puzzle why, after thousands of years in which man and the primates have lived together in Africa, the human infection should have made its epidemiologic appearance so recently.

As background, it is convenient to consider the nidality theory of infectious agents and the varied ways by which they interact with their hosts. In the resulting communities, each of the species which participate in them plays its own peculiar role in the sharing of the available resources called the ecological niche of the species (Forattini, 1992). When this is represented by an infectious agent, the infection which it brings about may eventually disappear, either in terms of place or time, if it shows itself to be an inefficient transmitter, i. e., if, on average,each hosts gives rise to less than new one. This may happen due to several factors, both natural and artificial. Among the former the development of immunity or the disappearance of the host populations, while the latter occurs when the transmission is interrupted by public health measures. As far as AIDS is concerned, there are more than one related human HIV viruses, similar to SIV and corresponding to the simian immunodeficiency viruses. Although the earliest know AIDS-related human death-is recognized as having occurred in the 1950s, it is believed that the infection arose in Central and East Africa, because that was where cases first began to appear frequently and where the related simian viruses occur naturally.

As a result of this there is a tendency to assume that the AIDS viruses spread from monkeys to the human population. In other words, it must be accepted that these viruses were able to occupy an available ecological nicie, interacting with the human population. It is not clear what mechanism was involved in this. Several aspects needs explanation. In the first place, the apparent harmlessness of SIVs in wild African monkeys, in contrast to the high virulence in humans. Second, as was already mentioned, why after thousands of years of co-existence has the HIV virus only recently appeared as epidemic. These questions seem to be the real mystery of the origin of AIDS.

Several types of explanation have been put forward. Starting from the simple opportunistic sporadic behaviour, until becoming a frequent parasite, as a result of the changes in the human life style, such as urban concentration and the highly developed population exchange. Some have given attention to the various experimental malaria research projects undertaken during this present century, by which humans received blood from African monkeys. Notwithstanding, none of these is capable of explaning the question in an unquestionable manner (Diamond, 1992). Consequently, it is proper that other theories should be suggested.

It is well known that infectious agents may emerge in new forms in such a way as to cause disease epidemics. Some are related to changing human life-styles while others arise from new genetic variations (Krause, 1992). These may be represented by mutation in only a single nucleotide of DNA chain yet, even so, be crucial to the development of virulence. It is well known too that the rapid rate at which HIV mutates results in great potential for change in replication rates. It is for this reason that nonlatent HIV develops an increased replication rate in the interval between the onset of infection and death (Ewald, 1993). Otherwise, the progress of the anthropogenic invason of any species, along with the homogeinizing process among the populations of the invaded community, depends on essentially dynamic factors. In other words, the nature of the interactions between the invading species and those of the invaded community determines the success of the invasion (Lodge, 1993). However, so that this process may be successful and achieve the necessary stability, this interaction should either lead to the creation of a new ecologic niche or, otherwise, that it should establish itself in a niche which has become vacant. This last possibility becomes admissible when one considers the ways by which human activities eliminate species from the biosphere. And this extinction should not be thought of as simply relating to animals and plants in the course of major environmental alterations, but also as the result of the consciously achieved planning of the campaigns for the erradication of infectious diseases. This, from the ecological point of view, represents nothing less than the extinction of at least, one species, that of the infectious agent. In attaining this success, a vacant niche is created, which may then be taken over by another. It may be just a simple coincidence and therefore one is not here making statements categorical. However, it cannot but be considered as curious that, as regards time of occurrence, the AIDS pandemic followed hard on the heels 
of the world-wide erradication of smallpox. And, in terms of geography, that this latter is supposed last to have become extinct precisely in Africa on which Continent the former first arose as epidemic. In other words, that this should have occurred precisely in that region of the world where the existing and previously innocuous SIV was "awaiting" this opportunity.

S. Paulo, June 1993

\author{
Oswaldo Paulo Forattini \\ Editor \\ Department of Epidemiology \\ School of Public Health \\ University of S. Paulo
}

References

See Portuguese version 